\title{
China Shocks and Their Employment Effects in Emerging Economies
}

\author{
Bambang Suprayogi $i^{*}$, T. M Harchaoui ${ }^{2}$ \\ ${ }^{*}$ Corresponding author
}

\begin{abstract}
The impact of "China shocks" on trading partners is a source of a massive supply shock that displaces foreign manufacturing producers, and an important source of demand shock that propelled forward a wide range of foreign sectors. The "common" existing literature mainly focused on the supply shock and its impact, leaving a large span of "China shocks" unexplained. Thus, this article undertake the important task to account for the dual track of "China shocks" and their impacts on a set of emerging economies, for which the evidence remains scanty. Using a global input-output methodology which highlights the job creation from exports and the job destruction aspect of imports, we provide evidence on the employment effect of bilateral trade with China. Our results suggest that considering the net effect of supply and demand related to China shocks mainly lead to negative job demand, and press the ringing bell for the government.
\end{abstract}

Keywords: China shocks, employment, trade, export import, emerging economies

\begin{abstract}
Abstrak
Dampak dari syok China terhadap mitra dagang merupakan sumber dari syok penawaran yang akan menggeser produsen manufaktur asing dan sumber dari syok permintaan yang dapat menumbubkan berbagai sektor di luar negeri. Literatur yang ada kebanyakan fokus terhadap dampak dari impor dan tidak menjelaskan efek dari syok China secara keseluruhan (ekspor dan impor). Oleh karena itu, artikel ini mencoba menjawab pertanyaan tersebut dengan melakukan penelitian di negara berkembang dimana penelitian terhadap efek dari perdagangan bilateral dengan China masih sulit ditemukan. Artikel ini akan menggunaka metode input-output yang akan menghitung jumlah penambahan permintaan tenaga dari ekpor dan jumlah pengurangan dari impor. Kami mendapatkan hasil bahwa perdagangan bilateral dengan China baik ekspor maupun impor secara umum memberikan efek negatif terhadap permintaan tenaga kerja, oleh karena itu pemerintah dalam hal ini harus waspada.
\end{abstract}

Kata Kunci: goncangan Cina, tenaga kerja, perdagangan, ekspor impor, perekonomian negara berkembang

JEL Classification: F1, F16, F66

\section{How to Cite:}

Suprayogi, B., \& Harchaoui, T. M. (2020). China Shocks and Their Employment Effects in Emerging Economies. Signifikan: Jurnal Ilmu Ekonomi, Vol. 9(1), 31-50. doi: http://dx.doi.org/10.15408/sjie.v9i1.13550. 


\section{Introduction}

The rise of China as powerhouse exporter of manufacturing goods and its impact on developed economies labor markets has been the focus of an active line of research. China had made a clear shift from labour-intensive to capital and technology intensive export (Caporale et al., 2015). Beginning with the landmark contribution by Autor et al (2013, 2014, $2015 \& 2016$ ) which stressed that rising exposure to China's imports adversely affect U.S. local labor markets, this research theme has been extended to other developed nations, including United States (Asquith et al., 2019), France (Malgouyres, 2017), Italy (Federico, 2013), Belgium (Mion \& Zhu, 2013), Norway (Balsvik et al, 2014), and Japan (Taniguchi, 2019). The import penetration from China caused South African manufacturing output to be 5 percent lower (Edwards \& Jenkins, 2015). The import penetration from China also make a negative effect on inflation in Zimbabwe (Makoto \& Ngendakumana, 2018)

While this literature has advanced our knowledge on "China shock" on a wide range set of developed nations, surprisingly the literature on developing nations remains scanty possibly the result of the earlier study conducted by Wood and Mayer (2011) who stressed that China's "...de-industrializing effect was significant, but not big enough to be a serious threat ... in most other developing countries”. Yet, more recent attempts by Iacovone et al. (2013) for Mexico, and Jenkins (2015) for Brazil seem to suggest that China's import competition translates into important reallocation effects in Mexico and hefty deindustrialization and "primarization" in Brazil. Nguyen et al. (2017) shows that import competition have reduced employment. However, the clear line on how "China shock" effects employment in emerging nations is still an open topic subject to discuss with very limited literature involved especially from global input-output methodology perspective.

Thus we contribute to this literature along several dimensions. First, we consider a representative sample of developing economies at a different stage of development with varying economic structures. This sample combines economies such as Brazil, Mexico, and Indonesia that possess a solid base in manufacturing which may be subject to imports completion from China and in natural resources which may be propelled by China's need to fuel its economy. At the other end of the spectrum, we include India and Turkey both of which offer a different perspective of development in their own right. The latter represents a clean case study of an economy subject to premature de-industrialization while the former is interesting given that its development path rests on market services, thus preventing a head-on competition with China. Second, we employ an approach that stresses the dual role of China's shock: on the one hand, it creates import competition and labor market dislocation; and on the other hand, it is a source of employment creation with the exports in destination to China. Third, the existing literature rarely provides evidence from global input-output methodology view in the developing economies included Indonesia as bilateral trade with China continues to grow and how employment demand react is difficult to find. Fourth, we bring deep data analysis by introducing several sectors not only manufacture but also resource and service sector.

This paper will be divided into several sections. In section 2 , we briefly outline the world input-output methodology which forms the core part of the modeling strategy of 
the employment effects of exports and imports. This method is introduced by Johnson \& Noguera (2012) and extended by many researcher included Los et al. (2015), and Feenstra \& Sasahara (2018). In Section 3, we depict the employment effect of exports, leaving the one for imports to Section 4. Section 5 points out the net effect of trade with China, and the concluding remarks are drawn in the last Section.

In section 3 we find that exports to China generate significant employment demand ranging from 54,000 jobs in Turkey to 1.76 million jobs in Brazil, a respective $0.3 \%$ and $2.4 \%$ advance compared to the employment level benchmark in 1995. The first common pattern that emerges is the importance of intermediate good exports as a source of employment demand. All countries posted above $75 \%$ contribution from intermediate good exports, with Mexico posting the smallest of contribution with $74 \%$ and a hefty $90 \%$ for Brazil. Secondly, from total employment demand, the magnitude of the resource sector is the highest for all countries except for Mexico. The magnitude varies across countries, in Brazil, the resource sector contributed $2 / 3$, Indonesia $61 \%$, India $60 \%$ and more than $1 / 3$ in Turkey. Section 4 provides empirical evidence of the detrimental effect of imports. In our preferred estimation, the detrimental effect occurs in all countries ranging from - 0.209 million job losses in Mexico up to -6.55 million jobs lost in India. The common pattern that emerges is the important role of the imports from merchandise sector which consists of resource and manufacturing sector. The merchandise sectors contribution to the total job losses varies across countries, ranging from $85 \%$ in Indonesia and more than 100\% in Mexico and Turkey. Another interesting fact is the input-output linkages between services and manufacturing sectors.

\section{Methods}

In this section we highlight our methodology to measure the extent to which emerging economies employment is dependent on export as well as import. We follow the extended approach by Los et al. (2015), and Feenstra \& Sasahara (2018), which an extension of a standard input-output decomposition technique from Leontief $(1936,1941)$ toward a multi-country setting. First, this article will describe the general form of global input-output framework that already available at WIOD database and the accounting framework how to calculate the employment effect from export and import afterward.

The WIOTs or world input-output tables in WIOD (world input-output database) contain global transaction not only domestic but also international transaction involving 41 countries $(\mathrm{N})$ and 35 industries (S) for each country (Timmer et al, 2014 \& 2015 ). Each country-industry (N S) generates gross output $(x)$ that used for final demand $(f)$ or intermediate good $(z)$ that needed for producing final goods. Because the relationship is not only between country to country, but also industry to industry, and consist of origin/source and destination per country-industry, we then symbolized with $(i)$ is the origin country, $(j)$ is the destination country, $(r)$ the origin/source of industry and $(s)$ the destination industry. We use standard assumption in the input-output model that each producer only produce one product with one price. Thus for gross output $(x)$ that produced by source industry $(r)$ in origin country $(i)$ can be used for intermediate good and final demand purposes both in 
domestic and abroad. Based on the conditions above, the output of source industry $r$ and country $i$ is the sum of sales of intermediate good and final good:

$$
x_{i, r}=\sum_{s} \sum_{j} z_{(i, r),(j, s)}+\sum_{j} f_{(i, r), j}
$$

The input-output coefficient is derived from dividing intermediate good with gross output, this coefficient reflects the input from source industry $r$ in a country $i$ needed to produce one unit of gross output in industry $s$ in country $j$ :

$$
a_{(i, r),(j, s)}=\frac{z_{(i, r),(j, s)}}{x_{(j, s)}}
$$

By using linear algebra and stacking the above equation, we can rewritten the equation (1) with the new equation below:

$$
\left[\begin{array}{c}
x_{1} \\
x_{2} \\
\vdots \\
x_{N}
\end{array}\right]=\left[\begin{array}{cccc}
A_{1,1} & A_{1,2} & \ldots & A_{1, N} \\
A_{2,1} & A_{2,2} & \ldots & A_{2,1} \\
\vdots & \vdots & \ddots & \vdots \\
A_{N, 1} & A_{N, 2} & \ldots & A_{N, N}
\end{array}\right]\left[\begin{array}{c}
x_{1} \\
x_{2} \\
\vdots \\
x_{N}
\end{array}\right]+\left[\begin{array}{c}
\sum_{j} f_{1, j} \\
\sum_{j} f_{2, j} \\
\vdots \\
\sum_{j} f_{N, j}
\end{array}\right]
$$

In the compact form, we can simplify the above equation as:

$$
\underset{S N \times 1}{x}=\underbrace{A}_{S N \times S N} \underset{S N \times 1}{x}+\underbrace{f}_{S N \times 1}
$$

where:

$$
\begin{gathered}
x_{i}=\left[\begin{array}{c}
x_{(i, 1)} \\
x_{(i, 2)} \\
\vdots \\
x_{(i, S)}
\end{array}\right], A_{i, j}=\left[\begin{array}{cccc}
a_{(i, 1)(j, 1)} & a_{(i, 1)(j, 2)} & \ldots & a_{(i, 1)(j, S)} \\
a_{(i, 2)(j, 1)} & a_{(i, 2)(j, 2)} & \ldots & a_{(i, 2)(j, S)} \\
\vdots & \vdots & \ddots & \vdots \\
a_{(i, S)(j, 1)} & a_{(i, S)(j, 2)} & \ldots & a_{(i, S)(j, S)}
\end{array}\right] \\
\text { and } f_{i, j}=\left[\begin{array}{c}
f_{(i, 1), j} \\
f_{(i, 2), j} \\
\vdots \\
f_{(i, S), j}
\end{array}\right]
\end{gathered}
$$

In this form, $x_{i}$ is a vector that consists of $S \times 1$ gross output for country $i, A_{i, j}$ is a matrix consist of $S \times S$ input coefficient between origin and destination country, and $f_{i, j}$ is a $S \times 1$ of final goods produced by country $i$ and consumed by country $j$.

Then by involving identity matrix, we can rewrite equation (2.2) as $(I-A) x=f$, where $I$ refer to an identity matrix $(S N \times S N)$ that consist of $(0)$ except for the main diagonal. This will come up with the famous Leontief inverse matrix (M) introduce by Leontief (1936), which is:

$$
x=(I-A)^{-1} f \text { or } x=M f
$$

This global Leontief inverse matrix M $(S N \times S N)$ consists of the element $\left(m_{(i, r),(j, s)}\right)$ describing how much extra production in US\$ needed in country-sector $(i, r)$ to fulfill one US\$ of final demand for product $s$ in country $j$ (Johnson \& Noguera, 2012). 
In order to calculate the employment effect caused by export, we will introduce the vector of employment coefficients (e).

$$
e=\left[\begin{array}{c}
e_{1} \\
e_{2} \\
\vdots \\
e_{N}
\end{array}\right] \text {, where } e_{i}=\left[\begin{array}{c}
e_{(i, 1)} \\
e_{(i, 2} \\
\vdots \\
e_{N(i, s)}
\end{array}\right]
$$

Each of country-industry employment coefficient $e_{(i, r)}$ deriving from employment (number of persons engaged) in each industry divided by gross output in that industry, $e_{(i, r)}=\frac{l_{i, r}}{x_{i, r}}$. The data of employment is taken from WIOD's Socio Economic Accounts.

Multiplying the diagonal matrix of $\hat{e}$ with right-hand side in equation (3), will result in equation explain that change in employment is the result of gross output induced by final demand:

$$
l=\widehat{e}(I-A)^{-1} f=\widehat{e} x
$$

Where $l$ is a vector of total actual employment with $S N \times 1$ in each of country-industry and $l_{i}$ is denote for a country-specific sector with $S \times 1$. In a word, changes in employment are modeled as results from changes in gross output induced by the changes from final demand.

On further modeling strategy, except for the export section, we follow the approach and methodology developed by Feenstra \& Sasahara (2018) that seek evidence for the USA on China shocks. While in the export section, We employ methodology as Los et al. (2015) that focus on the positive impact of exports from the demand side. By the method from Feenstra \& Sasahara (2018) on the import section and Los et al. (2015) in the export section, first, We can track the direct and indirect effect through the input-output linkages and secondly, it provides the broad view coverage not only manufacturing sector but also others (resources and services). In addition, we cooperated with the same period (1995-2011) and sectoral grouping. On the next section, we will discuss the impact of export and the impact for import afterward with the involving of the econometric approach.

\section{Result and Discussion \\ Employment Effects of Exports}

First, we symbolize each country as, BRA for Brazil, IDN for Indonesia, IND for India, MEX for Mexico and TUR for Turkey. Because we use data over 1995-2011, we use data in 1995 as a baseline and use Indonesia (IDN) as a representative symbol to simplifying the equation notation. The employment effect of Indonesian final goods exports (denoted by the superscript $\left.{ }^{E x_{f}, I D N}\right)$ in the period of 1995-2011 will be:

$$
\Delta l^{E x_{f}, I D N}=\hat{e}^{2011}\left(I-A^{2011}\right)^{-1} f^{2011}-\hat{e}^{2011}\left(I-A^{2011}\right)^{-1} f^{E x, I D N, 2011 *}
$$

The first term in the right-hand side $\left(\hat{e}^{2011}\left(I-A^{2011}\right)^{-1} f^{2011}\right)$ is a vector of actual employment in $2011\left(l^{2011}\right)$ consist of $S N \times 1$, while the second term is modified or manipulated term that differs from the first term where : 


$$
\underbrace{f^{E x, I D N, 2011 *}}_{S N \times 1}=\left[\begin{array}{cccccc}
f_{1,1}^{2011} & f_{1,2}^{2011} & \ldots & f_{1, I D N}^{2011} & \ldots & f_{1, N}^{2011} \\
f_{2,1}^{2011} & f_{2,2}^{2011} & \ldots & f_{2, I D N}^{2011} & \ldots & f_{2, N}^{2011} \\
\vdots & \vdots & \ddots & \vdots & \ddots & \vdots \\
f_{I D N, 1}^{1995} & f_{I D N, 2}^{1995} & \ldots & f_{I D N, I D N}^{2011} & \ldots & f_{I D N, N}^{1995} \\
\vdots & \vdots & \ddots & \vdots & \ddots & \vdots \\
f_{N, 1}^{2011} & f_{N, 2}^{2011} & \ldots & f_{N, I D N}^{2011} & \ldots & f_{N, N}^{2011}
\end{array}\right] \times \underbrace{\left[\begin{array}{c}
1 \\
1 \\
\vdots \\
1
\end{array}\right]}_{N \times 1}
$$

From equation (5), the superscript (Ex, IDN,2011*) refers to a hypothetical condition in 2011 where all final good exports from Indonesia to all trading partners (except domestic partner) are constant at 1995 level, and multiplying the first term in the righthand side with $N \times 1$ vector to take the row sum of the matrix. This manipulation is to isolate the portion of labor demand induced by final goods export of Indonesia from total final good production in the period of 1995-2011. The second term in equation (4) is the hypothetical global employment vector $S N \times 1$ where Indonesia final goods exports are at the 1995 level. This vector consist of Indonesia sub-vector $N \times 1$ that expected to be lower. The deviation between the first term (actual employment) and second term (hypothetical) in equation (4) is our interest as the change of employment due to Indonesia exports over 1995-2011. The result is expected to be positive if there is a growth in exports and the other way around. As this article interested in export to China only, thus we simply modified the equation (5) and only replaced the export to China with the 1995 level (equation 6) and use the equation (7) in order to calculate the employment effect due to export to China.

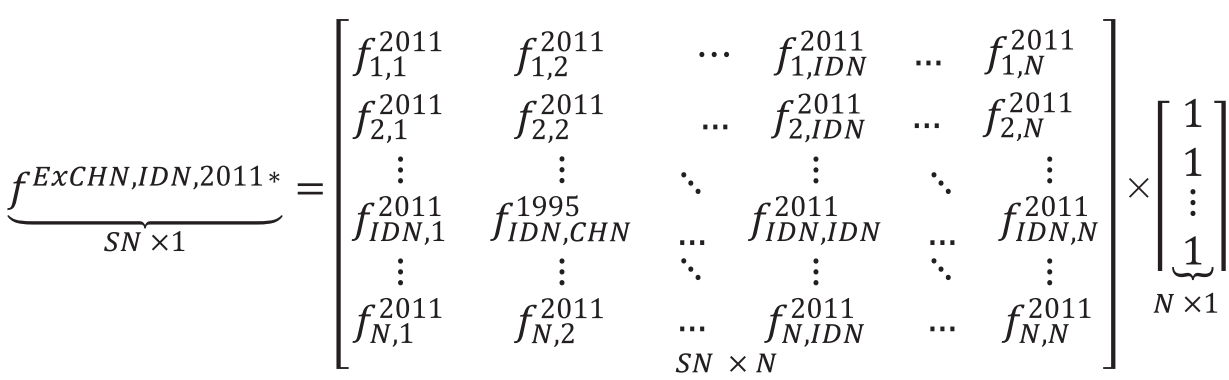

$\Delta l^{E x_{f C H N}, I D N}=\hat{e}^{2011}\left(I-A^{2011}\right)^{-1} f^{2011}-\hat{e}^{2011}\left(I-A^{2011}\right)^{-1} f^{E x C H N, I D N, 2011 *}$

With the same method, we calculate the effect not only from final goods export but also from intermediate goods to generate the total effect. Thus for the total effect from final and intermediate goods export to China $\left({ }^{\mathrm{EtotCHN}}\right)$, we have :

$$
\begin{aligned}
\Delta l^{\text {EtotCHN,IDN }=} & \hat{e}^{2011}\left(I-A^{2011}\right)^{-1} f^{2011}-\hat{e}^{2011} \\
& \left(I-A^{E x C H N, I D N, 2011 *}\right)^{-1} f^{E x C H N, I D N, 2011 *}
\end{aligned}
$$


The global hypothetical input-output coefficient then defined as :

$$
\underbrace{\boldsymbol{A}^{E x C H N, I D N, 2011 *}}_{S N \times S N}=\left[\begin{array}{cccccc}
\boldsymbol{A}_{1,1}^{2011} & \boldsymbol{A}_{1,2}^{2011} & \ldots & \boldsymbol{A}_{1, I D N}^{2011} & \ldots & \boldsymbol{A}_{1, N}^{2011} \\
\boldsymbol{A}_{2,1}^{2011} & \boldsymbol{A}_{2,2}^{2011} & \ldots & \boldsymbol{A}_{2, I D N}^{2011} & \ldots & \boldsymbol{A}_{2, N}^{2011} \\
\vdots & \vdots & \ddots & \vdots & \ddots & \vdots \\
\boldsymbol{A}_{I D N, 1}^{2011} & \boldsymbol{A}_{I D N, C H N}^{2011 *} & \ldots & \boldsymbol{A}_{I D N, I D N}^{2011} & \ldots & \boldsymbol{A}_{I D N, N}^{2011} \\
\vdots & \vdots & \ddots & \vdots & \ddots & \vdots \\
\boldsymbol{A}_{N, 1}^{2011} & \boldsymbol{A}_{N, 2}^{2011} & \ldots & \boldsymbol{A}_{N, I D N}^{2011} & \ldots & \boldsymbol{A}_{N, N}^{2011}
\end{array}\right]
$$

In equation (8) intermediate export goods from Indonesia to China $\boldsymbol{Z}_{I D N, C H N}^{1995}$ is set at 1995 level, while gross output is at 2011 level. This will result in the actual input-output coefficient matrix in 2011 except for Indonesia sub-matrix, which is:

$$
\underbrace{A_{I D N, C H N}^{2011 *}}_{S \times S}=\left[\begin{array}{cccc}
\frac{z_{(I D N, 1)(C H N, 1)}^{1995}}{x_{C H N, 1}^{2011}} & \frac{z_{(I D N, 1)(C H N, 2)}^{1995}}{x_{C H N, 2}^{2011}} & \ldots & \frac{z_{(I D N, 1)(C H N, S)}^{1995}}{x_{C H N, 1}^{2011}} \\
\frac{z_{(I D N, 2)(C H N, 1)}^{1955}}{x_{C H N, 1}^{2011}} & \frac{z_{(I D N, 2)(C H N, 2)}^{1995}}{x_{C H N, 2}^{2011}} & \ldots & \frac{z_{(I D N, 2)(C H N, S)}^{1995}}{x_{C H N, S}^{2011}} \\
\vdots & \vdots & \ddots & \vdots \\
\frac{z_{(I D N, S)(C H N, 1)}^{1995}}{x_{C H N, 1}^{2011}} & \frac{z_{(I D N, S)(C H N, 2)}^{1995}}{x_{C H N, 2}^{2011}} & \ldots & \frac{z_{(I D N, S)(C H N, S)}^{1995}}{x_{C H N, S}^{2011}}
\end{array}\right]
$$

The same interpretation applied for intermediate goods as the final good hypothetical matrix, when actual export from Indonesia arise, the hypothetical input coefficient should be lower and vice versa.

Based on the previous method, we will get the employment effect from intermediate and final good exports to China for each country (Brazil, Indonesia, India, Mexico, and Turkey). Avoiding the undesirable result from the calculation, we calculate the effect individually (separately) for each country. The undesirable results may occur if we do the calculation for all countries at once, for example, if Brazil and Indonesia held the final good export in the same 1995 level, and we calculate the effect for Brazil and Indonesia, the higher employment effect of this condition will occur. Because Brazil would lose the hypothetical intermediate good demand needed in Indonesia to produce final good exports and in other way around for Indonesia. Additionally, we divide the 35 industries into three categories (sector), namely the resource, manufacturing, and service sector.

$$
\begin{gathered}
\Delta l_{I N D, \text { Resource }}^{\text {EtotCHN,IDN }}=\sum_{r=1}^{3} \Delta l_{(I D N, r)}^{\text {EtotCHN,IDN }} \\
\Delta l_{\text {IDN,Manufacture }}^{\text {EtotCHN } \text { IDN }}=\sum_{r=4}^{16} \Delta l_{(I D N, r)}^{\text {Etot,IDN }} \\
\Delta l_{\text {IDN,Service }}^{\text {EtotCHN,IDN }}=\sum_{r=17}^{35} \Delta l_{(I D N, r)}^{\text {Etot,IDN }}
\end{gathered}
$$

The employment effect of exports due to intermediate and final goods export to China are reported in Table 1. 
Table 1. Employment Effect of Exports to China 1995-2011 (million workers)

\begin{tabular}{|c|c|c|c|c|c|}
\hline Sector & \multicolumn{2}{|c|}{$\begin{array}{c}\text { Through Final good exports } \\
\text { only }\end{array}$} & \multicolumn{2}{|c|}{$\begin{array}{l}\text { Through Final good and } \\
\text { intermediate exports }\end{array}$} & $\begin{array}{c}\text { Employment in } \\
1995\end{array}$ \\
\hline \multicolumn{6}{|c|}{ Brazil } \\
\hline Manufacturing & 0.015 & $0.2 \%$ & 0.116 & $1.5 \%$ & 7.8 \\
\hline Resource & 0.098 & $0.5 \%$ & 1.18 & $5.6 \%$ & 21 \\
\hline Services & 0.058 & $0.1 \%$ & 0.469 & $1.1 \%$ & 44.6 \\
\hline All Sectors & 0.172 & $0.2 \%$ & 1.765 & $2.4 \%$ & 73.5 \\
\hline \multicolumn{6}{|c|}{ Indonesia } \\
\hline Manufacturing & 0.027 & $0.3 \%$ & 0.128 & $1.6 \%$ & 7.9 \\
\hline Resource & 0.08 & $0.2 \%$ & 0.818 & $1.8 \%$ & 45.1 \\
\hline Services & 0.076 & $0.2 \%$ & 0.377 & $1.1 \%$ & 34.2 \\
\hline All Sectors & 0.184 & $0.2 \%$ & 1.324 & $1.5 \%$ & 87.2 \\
\hline \multicolumn{6}{|c|}{ India } \\
\hline Manufacturing & 0.63 & $2.0 \%$ & 1.31 & $4.2 \%$ & 31 \\
\hline Resource & 0.21 & $0.1 \%$ & 3.02 & $1.2 \%$ & 250 \\
\hline Services & 0.23 & $0.2 \%$ & 0.71 & $0.7 \%$ & 99.76 \\
\hline All Sectors & 1.07 & $0.3 \%$ & 5.04 & $1.3 \%$ & 380.79 \\
\hline \multicolumn{6}{|c|}{ Mexico } \\
\hline Manufacturing & 0.03 & $0.7 \%$ & 0.121 & $2.6 \%$ & 4.6 \\
\hline Resource & 0.00594 & $0.1 \%$ & 0.023 & $0.3 \%$ & 8.2 \\
\hline Services & 0.012 & $0.1 \%$ & 0.041 & $0.2 \%$ & 20.2 \\
\hline All Sectors & 0.048 & $0.1 \%$ & 0.185 & $0.6 \%$ & 33.1 \\
\hline \multicolumn{6}{|c|}{ Turkey } \\
\hline Manufacturing & 0.005 & $0.2 \%$ & 0.018 & $0.7 \%$ & 2.5 \\
\hline Resource & 0.004 & $0.0 \%$ & 0.019 & $0.2 \%$ & 9.7 \\
\hline Services & 0.002 & $0.0 \%$ & 0.016 & $0.2 \%$ & 8.3 \\
\hline All Sectors & 0.012 & $0.1 \%$ & 0.054 & $0.3 \%$ & 20.5 \\
\hline
\end{tabular}

Notes: Positive numbers mean that labor demand increase and negative numbers indicate reduced labor demand. Percentage numbers are the ratio of the employment effect to the employment in 1995. The 35 WIOD sectors are aggregated into three broad sectors: the natural resource sector (sectors 1-3), the manufacturing sector (sectors 4-16), and the service sector (sectors 17-35).

We can see in Table 1 that exports to China generate significant employment demand for all countries ranging from 54,000 jobs in Turkey to 5.04 million jobs in India or $0.3 \%$ and $1.3 \%$ in percentage point, respectively, compared to the employment level benchmark in 1995. The first broad pattern in this result is the important role of intermediate good export in generating employment demand. Brazil posted 90.25 $\%$ contribution from intermediate good exports. Indonesia $86.10 \%$, India 78.77\%, Mexico $74 \%$, and Turkey $77.78 \%$. Secondly, from total employment demand, resource sector contributed the most for all countries except for Mexico. The contribution varies across countries, in Brazil, the resource sector contributed 2/3, Indonesia more than 3/5, India $3 / 5$ and more than $1 / 3$ in Turkey. The magnitudes from the manufacturing sector in total labor demand vary across countries, Mexico reports the highest magnitude with 
$65 \%$ and only $6.6 \%$ in Brazil that is dominated by resource sector contribution. For further analysis, we decompose the impact of export into two different sectors namely merchandise and service sector. Table 2 shows the decomposition of export to China for merchandise and service sector.

Table 2. Employment Effect of Export to China (Merchandise versus service) 1995-2011 (million workers)

\begin{tabular}{|c|c|c|c|}
\hline \multirow[b]{2}{*}{ Sector } & \multirow[b]{2}{*}{$\begin{array}{l}\text { The Impact of final good } \\
\text { and intermediate exports } \\
\text { from all sectors }\end{array}$} & \multicolumn{2}{|c|}{ Decomposition } \\
\hline & & $\begin{array}{l}\text { The impact of final good } \\
\text { and intermediate exports } \\
\text { from merchandise sectors }\end{array}$ & $\begin{array}{l}\text { The impact of final good } \\
\text { and intermediate exports } \\
\text { from service sectors }\end{array}$ \\
\hline \multicolumn{4}{|c|}{ Brazil } \\
\hline Manufacturing & 0.116 & 0.115 & 0.001 \\
\hline Resource & 1.18 & 1.179 & 0.001 \\
\hline Services & 0.469 & 0.454 & 0.015 \\
\hline All Sectors & 1.765 & 1.75 & 0.015 \\
\hline \multicolumn{4}{|c|}{ Indonesia } \\
\hline Manufacturing & 0.128 & 0.126 & 0.002 \\
\hline Resource & 0.818 & 0.797 & 0.021 \\
\hline Services & 0.377 & 0.231 & 0.146 \\
\hline All Sectors & 1.324 & 1.154 & 0.17 \\
\hline \multicolumn{4}{|c|}{ India } \\
\hline Manufacturing & 1.309 & 1.305 & 0.004 \\
\hline Resource & 3.020 & 3.010 & 0.010 \\
\hline Services & 0.710 & 0.650 & 0.060 \\
\hline All Sectors & 5.041 & 4.966 & 0.075 \\
\hline \multicolumn{4}{|c|}{ Mexico } \\
\hline Manufacturing & 0.12136 & 0.12129 & 7E-05 \\
\hline Resource & 0.02309 & 0.02306 & $3 \mathrm{E}-05$ \\
\hline Services & 0.041 & 0.038 & 0.003 \\
\hline All Sectors & 0.185 & 0.183 & 0.002 \\
\hline \multicolumn{4}{|c|}{ Turkey } \\
\hline Manufacturing & 0.01846 & 0.01831 & 0.00015 \\
\hline Resource & 0.01907 & 0.0189 & 0.00017 \\
\hline Services & 0.01687 & 0.015 & 0.00187 \\
\hline All Sectors & 0.054 & 0.052 & 0.002 \\
\hline
\end{tabular}

Notes: Positive numbers mean that labor demand increase and negative numbers indicate reduced labor demand.

Again, we see the common patterns in Table 2. First, the employment effect of exports to China dominated by the contribution of merchandise exports in all countries. In Brazil, from 100 employments generate by exports, 99 is generated from merchandise export and only 1 from service. In Indonesia, 87 from merchandise export, 13 from service export. In India, the ratio is almost 50 again 1 for merchandise as similar to Mexico, while in Turkey is 24 versus 1 . The second pattern is the importance of linkages effect between services and 
merchandise sector. In all countries, the export of merchandise sectors generates significant job demand in services sector, ranging from $13 \%$ in India up to $29 \%$ in Turkey.

\section{Employment in Import}

In import, simply use the above method and change Chinese exports to the country of interest with the data from 1995 to analyze China shock may lead to the wrong conclusion because only by doing this as the case in USA, the USA imports from China have a positive employment effect. This result may occur as it neglected the fact that import penetration at the same time will affect domestic production (Feenstra \& Sasahara, 2018). Thus we have to modify the method either by using assumption in how domestic production reacts to China product or utilizing estimation result. We will use the later method in order to have a better result with more precise and accurate prediction that will be described in the next sub-section.

The employment effect in the country of interest due to the import of final goods from China will be obtained by:

$$
\Delta l^{I m_{f}, I D N}=\hat{e}^{2011}\left(I-A^{2011}\right)^{-1} f^{2011}-\hat{e}^{2011}\left(I-A^{2011}\right)^{-1} f^{I m, I D N, 2011 *}
$$

as similar to the previous term in the export section, the first term in right-hand side in equation (11) is global actual employment in 2011 and the second term is modified final demand with modified two vectors, the first vector is the vector of final goods export from China to Indonesia (Export China to Indonesia/ $f_{C H N, I D N}^{1995}$ ) by replacing 2011 value with 1995 and the second vector is final good from Indonesia to Indonesia (final demand for domestic production $/ f_{I D N, I D N}^{2011 *}$ ), equation (12). The last term (domestic production) will be derived from market shares regression estimation. The expectation from the regression is when import from China increase, reflected by the increasing of market shares of China's product in Indonesia and predicted to have a crowding-out effect by lowering domestic producer shares.

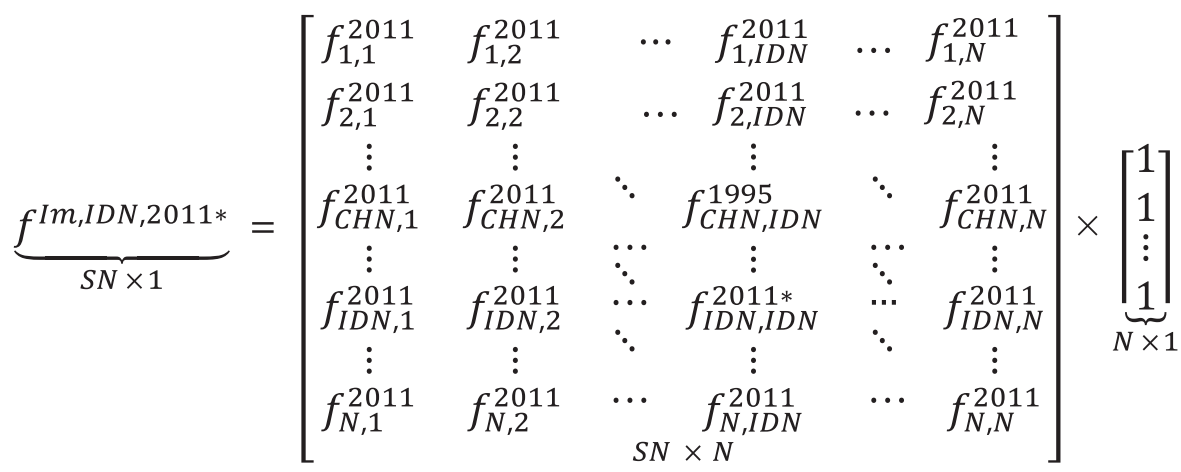

The general relationship between China market share and how domestic producers react is described in the specification (13):

$$
\underbrace{\frac{f_{(I D N, r), I D N}^{t}}{\sum_{i=1}^{N} f_{(i, r), I D N}^{t}}}_{I D S_{r}^{t}}=\beta_{0}+\beta_{1} \frac{f_{(C H N, r), I D N}^{t}}{\sum_{i=1}^{N} f_{(i, r), I D N}^{t}}+\beta_{r} \mu_{r}+\beta^{t} \pi^{t}+e_{r}^{t}
$$

In this specification, the independent variable $I D S_{r}^{t}$ is the market share of Indonesia final good producers in domestic market obtained by dividing domestic production in industry 
$r$ with total market value (total sales from all countries producers of $r$ in Indonesia final good market of $r$ ), and the explanatory variables on the right side consist of $\beta_{0}$ as intercept, $C S_{r}^{t}$ is the China market share of industry $\mathrm{r}$ in Indonesia market and thus $\beta_{1}$ is the "the pass-through" parameter or the coefficient that intended to catch the effect if China share increase, $\mu_{r}$ industry dummies, $\pi^{t}$ time dummies and $\varepsilon_{r}^{t}$ market-year specific error term. By this equation, we will have 595 observations ( 35 industries $/ R \times 17$ years/T). The estimated parameters in equation (13) will be used to construct a hypothetical market share for 35 sectors if China export in 2011 is at the same level of export in 1995.

$\operatorname{fshare}_{(I D N, r), I D N}^{2011 *}=\hat{\beta}_{0}+\hat{\beta}_{1} \frac{f_{(C H N, r), I N D}^{1995}}{\sum_{i \neq C H N}^{N} f_{(i, r), I D N}^{2011}+f_{(C H N, r), I D N}^{1995}}+\hat{\beta}_{r} \hat{\mu}_{r}+\hat{\beta}^{2011} \hat{\pi}^{2011}+\hat{\epsilon}_{t}^{2011}$

In the second term of the right-hand side, the denominator is the total of product sales in Indonesia final goods market share with hold for China constant sale in 1995, and the numerator is export China to Indonesia also in 1995. The other parameters included the intercept, industry dummies, and specific year fixed-effect are to make sure that the different between counter-factual and the actual market shares is determined only by the constant constructed value of China export. The result of this manipulated share that range between 0 and 1, will multiply by the actual share in 2001. By this multiplication, the elements of hypothetical domestic production will be obtained $f_{I D N, I D N}^{2011 *}$.

$$
f_{(I D N, r) I D N}^{2011 *}=\left(\operatorname{fshare}_{(I D N, r), I D N}^{2011 *}\right) \sum_{i=1}^{N} f_{(i, r), I D N}^{2011}
$$

Similar to the final goods procedure, intermediate goods import are incorporated by :

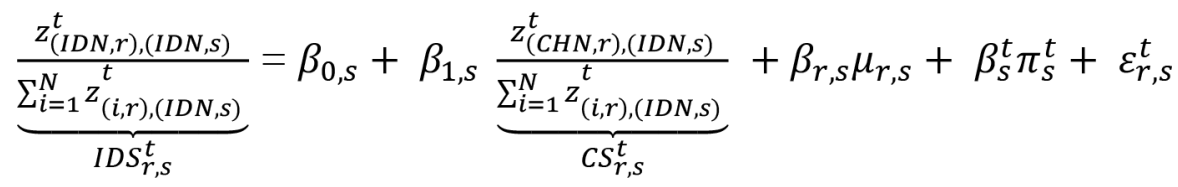

The independent variable in the left side $I D S_{r, s}^{t}$ is the share of Indonesia intermediate good in the domestic market and the explanatory variable $C S_{r, s}^{t}$ is Chinese intermediate good share in Indonesia market. We then running (175 regression) or 35 regression for each country refers to each intermediate good market. After running the regressions, we will have $S \times S$ hypothetical share for $2011^{*}$ or $\operatorname{Zshare} e_{(I D N, r),(I D N, s) \text {. }}^{2011 *}$

In the market regression part, we differ from the approach utilized by Feenstra and Sasahara (2018) with the OLS and IV regression approach. For the former (OLS), the econometric issues may arise in the fact that first, the dependent (domestic share) and explanatory variable (China share) incorporate total demand, and the involving of measurement error. While the later (IV) may create the "instrument proliferation", the problem that not only over fits the endogenous variables but also weakens the power of invalidity test of the instrument (Roodman, 2009), because the number of instruments involved (122) exceeds the number of cross-sectional groups (35) (Baltes \& Harchaoui, 2018). These problems, rendering unstable results with very much negative and positive variation across countries on our experimental regression and calculation (results are not presented). Thus, we corporate the regression part with two different approaches namely differentGMM and differentGMM subsets. 
Table 3. Estimation Result, dep. variable = domestic market share in the domestic market (Indonesia)

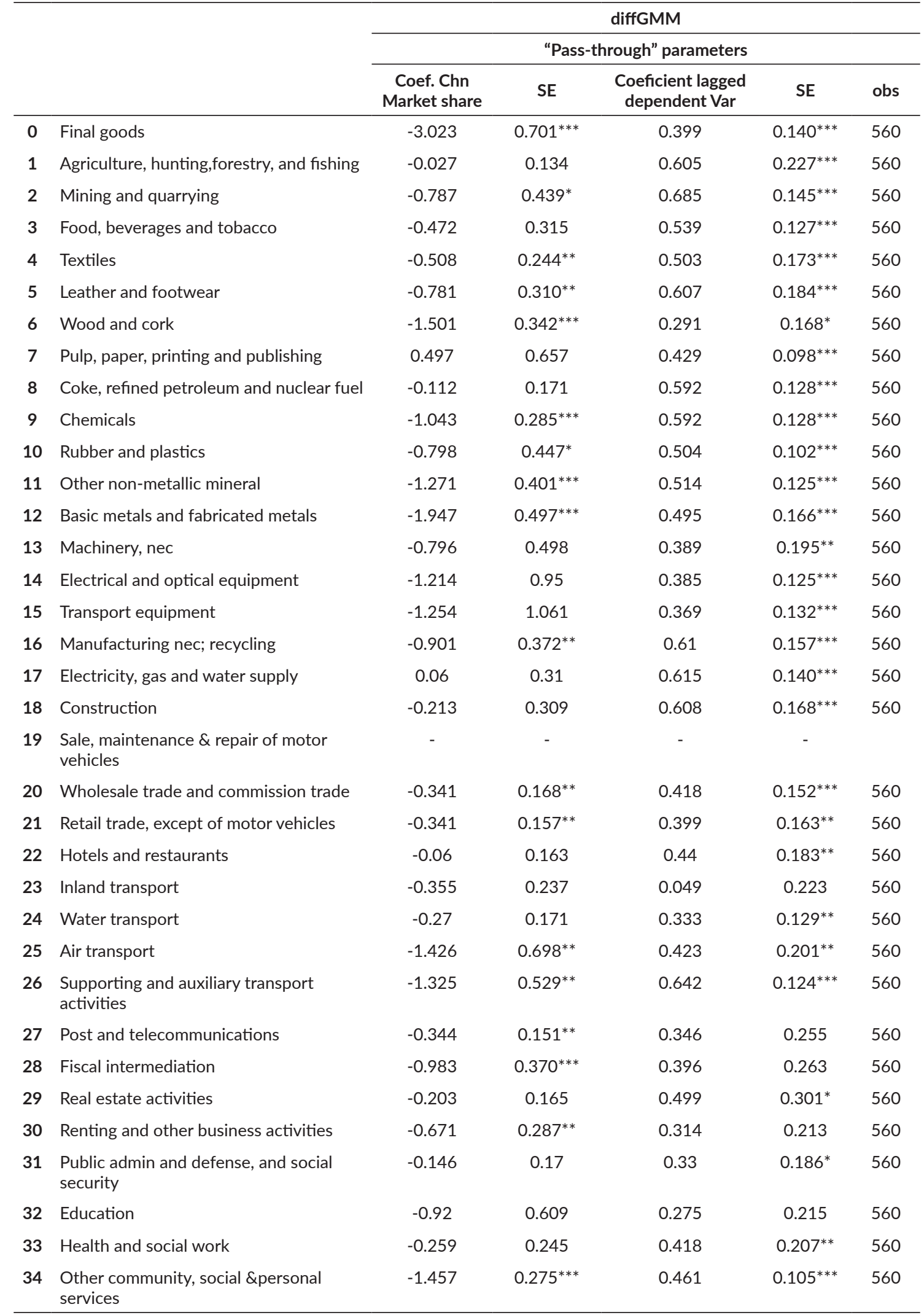

Note: this regression estimation includes a constant term, lag of dependent variable, year-fixed effect, robust standard error and treat China share as endogenous variable, and for int. Med. Industry\#19 observations are dropped by Stata, parentheses. ${ }^{* * *},{ }^{* *}$, and ${ }^{*}$ indicate statistical significance at $1 \%, 5 \%$, and $10 \%$ level. 
The main difference between these two is that the later specification is allowing different coefficients between the cross-sections (merchandise and service) and thus we have to run different regression per destination industry. The approaches, however, deal with the possibility of endogeneity by using the Arellano-Bond estimator and uses a fewer instrument in order to hinder the possibility of "instrument proliferation" problem.

The results from the market-share regression using diffGMM are presented in Table 3 (i.e Indonesia). The result of diffGMM shows that for final good the regression posted significant negative coefficient implies that for final goods, the domestic share negatively correlated with the China share or when China share increase will lead to a decrease of domestic share and adversely. In intermediate goods regression, the coefficients of China market share vary across sectors. Given these estimated regressions, the predicted intermediate share of domestic production in Indonesia will be calculated as (17) and (18):

$\operatorname{zshare}_{(I D N, r),(I D N, s)}^{2011 *}=\hat{\beta}_{0, s}+\hat{\beta}_{1, s} \frac{z_{(C H N, r),(I D N, s)}^{1995}}{\sum_{i \neq C H N}^{N} z_{(i, r),(I D N, s)}^{2011}+z_{(C H N, r),(I D N, s)}^{1995}}+\hat{\beta}_{r, s} \hat{\mu}_{r, s}+\hat{\beta}_{s}^{2011} \widehat{\pi}_{s}^{2011}+\hat{\epsilon}_{t, s}^{2011}$

These results multiplied with the actual total demand for intermediate goods in Indonesia to construct the hypothetical intermediate good production.

$z_{(I D N, r)(I D N, s)}^{2011 *}=\operatorname{zshare}_{(I D N, r),(I D N, s)}^{201 *} \sum_{i=1}^{N} z_{(i, r),(I D N, s)}^{2011}$

and replacing actual intermediate goods with the above results will give the coefficient input matrix where China’s export value to the country of interest is at 1995 level.

$\underbrace{A_{I D N, I D N}^{2011 *}}_{S \times S}=\left[\begin{array}{cccc}\frac{z_{(I D N, 1)(I D N, 1)}^{2011 *}}{x_{I D N, 1}^{2011}} & \frac{z_{(I D N, 1)(I D N, 2)}^{2011 *}}{x_{I D N, 2}^{2011}} & \cdots & \frac{z_{(I D N, 1)(I D N, S)}^{2011 *}}{x_{I D N, S}^{2011}} \\ \frac{z_{(I D N, 2)(I D N, 1)}^{2011 *}}{x_{I D N, 1}^{2011}} & \frac{z_{(I D N, 2)(I D N, 2)}^{2011 *}}{x_{I D N, 2}^{2011}} & \ldots & \frac{z_{(I D N, 2)(I D N, S)}^{2011 *}}{x_{I D N, S}^{2011}} \\ \vdots & \vdots & \ddots & \vdots \\ \frac{z_{(I D N, S)(I D N, 1)}^{2011 *}}{x_{I D N, 1}^{2011}} & \frac{z_{(I D N, s)(I D N, 2)}^{2011}}{x_{I D N, 2}^{2011}} & \ldots & \frac{z_{(I D N, S)(I D N, S)}^{2011 *}}{x_{I D N, S}^{2011}}\end{array}\right]$

We then calculate the job demand effect due to import goods from China both from intermediate and final goods:

$\Delta l^{I t o t, I D N}=\hat{e}^{2011}\left(I-A^{2011}\right)^{-1} f^{2011}-\hat{e}^{2011}\left(I-A^{I m, I D N, 2011 *}\right)^{-1} f^{I m, I D N, 2011 *}$

Where the hypothetical input coefficient matrix will be constructed as follow (11). from equation (21) the sub-matrix of $A_{C H N, I D N}^{2011 *}$, or the manipulated input-output coefficient from China to Indonesia is constructed by dividing the Chinese intermediate good export to Indonesia $z_{(C H N, r),(I D N, s)}^{1995}$ with total gross output in Indonesia $x_{I D N, S}^{2011}$. For the sub-matrix of intermediate input-output in Indonesia $A_{I D N, I D N}^{2011 *}$ we obtained from (4.9). While we don't have to categorize in final goods to 35 industries, in intermediate goods we have to run 35 regression for each country to constructs the hypothetical domestic intermediate production.

From equation (20) the sub-matrix of $A_{C H N, I D N}^{2011 *}$, or the manipulated input-output coefficient from China to Indonesia is constructed by dividing the Chinese intermediate good export to Indonesia $z_{(C H N, r),(I D N, S)}^{1995}$ with total gross output in Indonesia $x_{I D N, S}^{2011}$. For the sub- 
matrix of intermediate input-output in Indonesia $A_{I D N, I D N}^{2011 *}$ we obtained from (19). While we don't have to categorize in final goods to 35 industries, in intermediate goods we have to run 35 regression for each country to constructs the hypothetical domestic intermediate production.

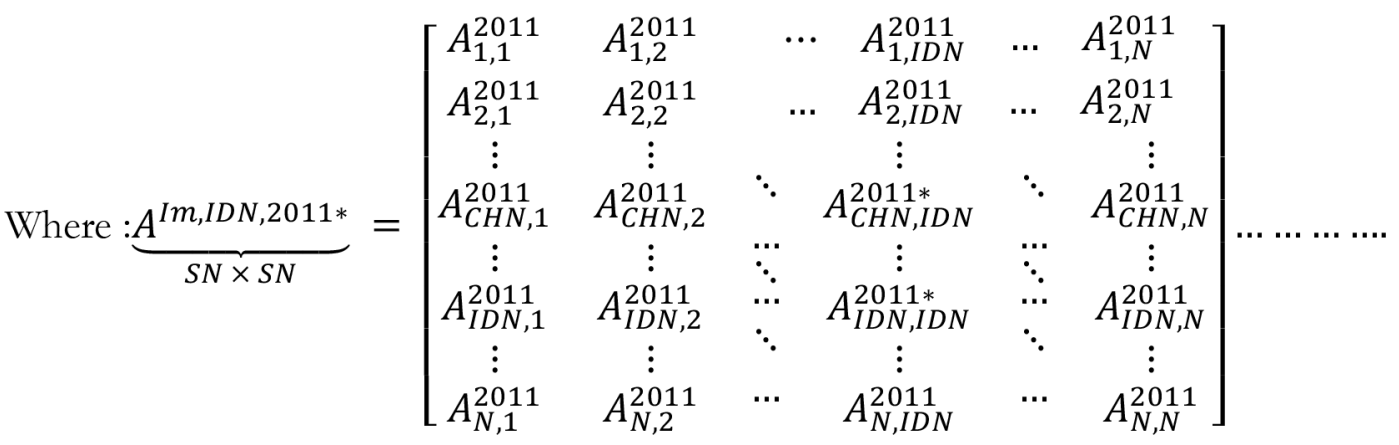

The results from using predicted domestic intermediate and final goods production using diffGMM are posted in Table 4. The first column of the result depicts the impact of all China goods import on employment demand, while the second column is the result of imports from merchandise sectors and the last column from service sectors. Table 4 shows the detrimental effect of import especially in trade with China. In our preferred estimation for domestic production share using diffGMM, the detrimental

effect occurs in all countries ranging from -0.209 million job lost in Mexico up to 6.55 job lost in India in all sectors. The general pattern that has to be emphasized in the result is the important role of the import from merchandise sectors. The merchandise sectors significant contribution vary across countries from $85 \%$ in Indonesia and even more than $100 \%$ in Mexico and Turkey (as the effect compensates by service sector). Another interesting fact is the input-output linkages between services and manufacturing sector. For example, in Brazil, from -0.815 million job losses in the service sector, -0.735 million or $90 \%$ is the contribution from input-output linkages or indirect linkages from manufacturing sectors. The others posted different magnitude, Indonesia 66\%, India $97 \%$, for Mexico $100 \%$ and Turkey indirect linkages somehow compensate by the direct linkage (services-services). This implies that job losses in the service sectors are mainly caused by manufacturing goods import.

\section{Net Employment Effect}

This section provides the net employment effect from trade with China from the country of interest. The net effect is calculated by juxtaposing the positive employment effect from export deducted by detrimental or negative effect from import. Table 5 summarizes the net effect of trade (export and import) with China over 1995-2011. 
Table 4. Employment Effect of Merchandise versus Service Imports from China, while Estimating domestic Production, diffGMM 1995-2011 (million workers)

\begin{tabular}{|c|c|c|c|}
\hline \multirow[b]{2}{*}{ Sector } & \multirow[b]{2}{*}{$\begin{array}{l}\text { The Impact of final good } \\
\text { and intermediate import } \\
\text { from all sectors }\end{array}$} & \multicolumn{2}{|c|}{ Decomposition } \\
\hline & & $\begin{array}{l}\text { The impact of final good } \\
\text { and intermediate import } \\
\text { from merchandise sectors }\end{array}$ & $\begin{array}{l}\text { The impact of final good } \\
\text { and intermediate import } \\
\text { from service sectors }\end{array}$ \\
\hline \multicolumn{4}{|c|}{ Brazil } \\
\hline Manufacturing & -0.733 & -0.733 & -0.0007 \\
\hline Resource & -0.12 & -0.12 & -0.0003 \\
\hline Services & -0.815 & -0.735 & -0.0800 \\
\hline All Sectors & -1.67 & -1.589 & -0.0810 \\
\hline \multicolumn{4}{|c|}{ Indonesia } \\
\hline Manufacturing & -1.21 & -1.20 & -0.010 \\
\hline Resource & -1.116 & -1.06 & -0.050 \\
\hline Services & -1.415 & -0.93 & -0.481 \\
\hline All Sectors & -3.74 & -3.19 & -0.553 \\
\hline \multicolumn{4}{|c|}{ India } \\
\hline Manufacturing & -3.87 & -3.871 & -0.002 \\
\hline Resource & -0.901 & -0.839 & -0.062 \\
\hline Services & -1.78 & -1.736 & -0.045 \\
\hline All Sectors & -6.55 & -6.447 & -0.103 \\
\hline \multicolumn{4}{|c|}{ Mexico } \\
\hline Manufacturing & -0.149 & -0.149 & -0.001 \\
\hline Resource & -0.011 & -0.011 & -0.000 \\
\hline Services & -0.048 & -0.049 & 0.001 \\
\hline All Sectors & -0.209 & -0.21 & 0.001 \\
\hline \multicolumn{4}{|l|}{ Turkey } \\
\hline Manufacturing & -0.251 & -0.256 & 0.005 \\
\hline Resource & -0.026 & -0.029 & 0.003 \\
\hline Services & -0.006 & -0.085 & 0.079 \\
\hline All Sectors & -0.284 & -0.371 & 0.087 \\
\hline
\end{tabular}

Notes: Positive numbers mean that labor demand increase and negative numbers indicate reduced labor demand

In Table 5, column 2 is the net effect of trade in all sector included merchandise and service sector. This column shows the detrimental net effect of trade with China in all country of interest except for Brazil. Firstly, we will discuss the former result and the later afterward. The negative net results are adversely compared to Feenstra and Sasahara (2018) that posted positive net demand for the USA. In Indonesia, the positive net effect from exports corroborates the previous result from Feenstra and Sasahara (2019) and Kiyota (2016) that export is the source of employment demand. However, we deviated the lower magnitude for the export with $2.4 \%$ growth compared to $16 \%$ growth in Feenstra \& Sasahara paper. While trade with China juxtaposing the job creation and job destruction in the opposite direction and cancel out each other (Ooi, 2016), we find that 2.42 million job losses or (2.8\%) compared to employment level in 1995. As opposed to the others, Brazil shows surprising result with 
positive net employment effect in trade with China. Nearly of 100,000 job demand is created in the period of $1995-2011$ or $0,1 \%$ compared to employment level in 1995 . The similar results can be found at other studies such as the USA (Feenstra and Sasahara, 2018), in Germany and The Netherlands (Baltes and Harchaoui, 2018), in The Czech Republic and Slovakia (Albers and Kander,2018).

Table 5. Net Employment Effect of Trade estimated domestic producer via diff GMM

\begin{tabular}{|c|c|c|c|c|c|}
\hline Sector & $\begin{array}{l}\text { Net Effect } \\
\text { from all sector }\end{array}$ & \% 1995 & Sector & $\begin{array}{l}\text { Net Effect from } \\
\text { Merchandise sector }\end{array}$ & \% 1995 \\
\hline \multicolumn{6}{|c|}{ Brazil } \\
\hline Manufacturing & -0.62 & $-7.9 \%$ & Manufacturing & -0.62 & $-7.9 \%$ \\
\hline Resource & 1.06 & $5.0 \%$ & Resource & 1.06 & $5.0 \%$ \\
\hline Services & -0.35 & $-0.8 \%$ & Services & -0.28 & $-0.6 \%$ \\
\hline All Sectors & 0.10 & $0.1 \%$ & All Sectors & 0.16 & $0.2 \%$ \\
\hline \multicolumn{6}{|c|}{ Indonesia } \\
\hline Manufacturing & -1.08 & $-13.7 \%$ & Manufacturing & -1.07 & $-13.6 \%$ \\
\hline Resource & -0.29 & $-0.6 \%$ & Resource & -0.26 & $-0.6 \%$ \\
\hline Services & -1.03 & $-3.0 \%$ & Services & -0.70 & $-2.0 \%$ \\
\hline All Sectors & -2.42 & $-2.8 \%$ & All Sectors & -2.04 & $-2.3 \%$ \\
\hline \multicolumn{6}{|c|}{ India } \\
\hline Manufacturing & -2.56 & $-8.3 \%$ & Manufacturing & -2.57 & $-8.3 \%$ \\
\hline Resource & 2.12 & $0.8 \%$ & Resource & 2.17 & $0.9 \%$ \\
\hline Services & -1.07 & $-1.1 \%$ & Services & -1.09 & $-1.1 \%$ \\
\hline All Sectors & -1.51 & $-0.4 \%$ & All Sectors & -1.48 & $-0.4 \%$ \\
\hline \multicolumn{6}{|c|}{ Mexico } \\
\hline Manufacturing & -0.03 & $-0.6 \%$ & Manufacturing & -0.03 & $-0.6 \%$ \\
\hline Resource & 0.01 & $0.1 \%$ & Resource & 0.01 & $0.1 \%$ \\
\hline Services & -0.01 & $0.0 \%$ & Services & -0.01 & $-0.1 \%$ \\
\hline All Sectors & -0.02 & $-0.1 \%$ & All Sectors & -0.03 & $-0.1 \%$ \\
\hline \multicolumn{6}{|c|}{ Turkey } \\
\hline Manufacturing & -0.23 & $-9.3 \%$ & Manufacturing & -0.24 & $-9.5 \%$ \\
\hline Resource & -0.01 & $-0.1 \%$ & Resource & -0.01 & $-0.1 \%$ \\
\hline Services & 0.01 & $0.1 \%$ & Services & -0.07 & $-0.8 \%$ \\
\hline All Sectors & -0.23 & $-1.1 \%$ & All Sectors & -0.32 & $-1.6 \%$ \\
\hline
\end{tabular}

In India, we find more than twice as much as the finding form Vashict (2016). On the growth accounting method, He found that trade with China is responsible for 607,000 job losses on the manufacturing sector, while we posted 2.56 million job losses. The interesting fact from the result is the positive contribution from resource sector to the negative net effect. While we don't have definitive reason assessment, the fact that the share of output and employment of resource sector depict declining trend and shift away to either manufacturing or service sector (Papola, 2012), the positive net effect implies that without import intermediate or final goods from China, the declining share may become even sharp in this period. 
For Mexico, the net effect of trade is relatively small in the magnitude compared to other countries. However, we bring a piece of evidence of the detrimental effect on trade with China, especially in the manufacturing sector with 30,000 job losses. The result corroborates the previous work from Iacovone et al (2013) that underlining the destruction on product and plant level from trade and the significant degree of workers mobility caused by the negative trade shock (Mendez, 2015). Import competition reduces negative self-selection of migrants to the US (Majlesi \& Narciso, 2018).

In Turkey, we find that the employment losses due to bilateral export and import activities with China is 0.23 million contributed mostly by the manufacturing sector job losses. This finding in line with the literature on the perspective of job losses. Akkus (2014) stated that as $1 \%$ increase in export demand causes sectoral employment to increase by $0.23 \%$, the same amount of increase in import competition causes a $0.33 \%$ decrease in sectoral employment in manufacturing industry.

\section{Conclusion}

This article tries to contribute the limited literature on China's shock effect on employment mainly in the developing countries using a world input-output approach in the period of 1995-2011. Featuring dual assessments accounting framework from export and import creation or destruction for employment demand, following Feenstra \& Sasahara (2018) approach. In the export section, we found that export to China mainly for intermediate goods is an important source in all countries in order to generate job demand. Decomposing export into merchandise and service sector, we found a robust result for the important of the first compared to the last. On the other hand, imports from China also have a detrimental effect on employment. Using two different regression approach, in our preferred approach (diffGMM), we found that import merchandise product from China responsible the most for the negative employment demand in all countries of interest. Juxtaposing the two effect we report the net effect from trade with China. We find that Indonesia experiences the most negative employment loss with -2.42 million. India coming second in employment loss with -1.51 million, Turkey with -0.23 million, Mexico -0.02 million and we find a surprising effect in Brazil with 0.1 million job demand gain. In the net effect from merchandise sectors, we find the significant contribution of merchandise trade of total net effect in all countries. By these results, the emerging economies should aware the consequences as results from bilateral trade with China especially related to employment demand because the affordable China products may live up the economy at a price.

However, we have to take into account some of the limitations that arise in this article. First of all, the WIOTs is modeled from the demand side of labor, thus the employment effect in this paper can be interpreted as the employment demand from trade (exports or imports). Second, the WIOT values are expressed in current US\$, in matrix manipulations approach, we replace the values in 2011 with 1995 values (current values at 1995) this manipulation somehow resulting higher employment effect compared to adjusted value if we corporate with base price or taking into account the inflation rate. Third, the understated or overstated 
employment effect may arise on the export expansion depend on the level of the data. In this case, WIOTs is based the ISIC rev 3 and mostly at the- 2 digit (Timmer et al, 2014). The understated may arise if the share of employment of exporting firms higher than nonexporter and the other way around in case of overstated.

\section{References}

Akkus, G. (2014). The Effects of Trade and Productivity on Employment in The Manufacturing Industry of Turkey. Journal of the Faculty of Economics, 64(5), 1-44.

Albers, L., \& Kander, A. (2018). The Impact of The "China Shock" on Employment Levels in Central Europe. Working Paper. Lund University.

Asquith, B., Goswami, S., Neumark, D., Rodriguez-Lopez, A. (2019). U.S. Job Flows and the China Shock. Journal of International Economics, 118, 123-137. https://doi. org/10.1016/j.jinteco.2019.02.002.

Autor, D. H., Dorn, D., \& Hanson, G. H. (2013). The China syndrome: Local labor market effects of import competition in the United States. American Economic Review, 103(6), 2121-2168. https://doi.org/10.1257/aer.103.6.2121

Autor, D. H., Dorn, D., \& Hanson, G. H. (2015). Untangling Trade and Technology: Evidence from Local Labour Markets. Economic Journal, 125(584), 621-646. https:// doi.org/10.1111/ecoj.12245

Autor, D. H., Dorn, D., \& Hanson, G. H. (2016). The China Shock: Learning from LaborMarket Adjustment to Large Changes in Trade. Annual Review of Economics, 8, 205240. https://doi.org/10.1146/annurev-economics-080315-015041

Autor, D. H., Dorn, D., Hanson, G. H., \& Song, J. (2014). Trade Adjustment: WorkerLevel Evidence. The Quarterly Journal of Economics, 129(4), 1799-1860. https://doi. org/10.1093/qje/qju026.Advance

Balsvik, R., Jensen, S., \& Salvanes, K. G. (2014). Made in China, Sold in Norway: Local Labor Market Effects of an Import Shock. Journal of Public Economics, 127, 137-144. https://doi.org/10.1016/j.jpubeco.2014.08.006

Baltes, T., \& Harchaoui, T. M. (2018). Assessing China’s Shock on European Union Labor Markets. (Unpublished Thesis). University of Groningen, Groningen, The Netherland.

Caporale, G. M., Sova, A., \& Sova, R. (2015). Trade Flows and Trade Specialisation: The Case of China. China Economic Review, 34, 261-273. https://doi.org/10.1016/j.chieco .2015.03.010.

Edwards, L., \& Jenkins, R. (2015). The Impact of Chinese Import Penetration on the South African Manufacturing Sector. The Journal of Development Studies, 51(4), 447-463. https://doi.org/10.1080/00220388.2014.983912.

Federico, S. (2014). Industry Dynamics and Competition from Low-Wage Countries: Evidence on Italy. Oxford Bulletin of Economics and Statistics, 76(3), 389-410. https:// doi.org/10.1111/obes. 12023

Feenstra, R.C., Sasahara, A. (2019). The 'China Shock' in trade: consequences for Asean and 
east Asia. In: Ing, L. Y., \& Yu, M. (Eds.), World Trade Evolution: Growth, Productivity and Employment. New York: Routledge

Feenstra, R. C., \& Sasahara, A. (2018). The 'China shock', Exports and U.S. Employment : A Global Input-Output Analysis. Review of International Economics, 26(5), 1053-1083. https://doi.org/10.1111/roie.12370

Iacovone, L., Rauch, F., \& Winters, L. A. (2013). Trade as an Engine of Creative Destruction: Mexican Experience with Chinese Competition. Journal of International Economics, 89(2), 379-392. https://doi.org/10.1016/j.jinteco.2012.09.002

Jenkins, R. H. Y. S. (2015). Is Chinese Competition Causing Deindustrialization in Brazil? Latin American Perspectives, 42(205), 42-63. https://doi.org/10.1177/0094582 X15593553

Johnson, R. C., \& Noguera, G. (2012). Accounting for Intermediates: Production Sharing and Trade in Value Added. Journal of International Economics, 86(2), 224-236. https:// doi.org/10.1016/j.jinteco.2011.10.003

Kiyota, K. (2016). Exports and Employment in China, Indonesia, Japan, and Korea. Asian Economic Papers, 15(1), 84-103. https://doi.org/10.1162/ASEP

Leontief, W. W. (1936). Quantitative Input and Output Relations in the Economic Systems of the United States. The Review of Economics and Statistics, 18(3), 105-125. https:// doi.org/10.2307/1927837

Los, B., Timmer, M. P., \& de Vries, G. J. (2014). How Important are Exports for Job Growth in China? A Demand Side Analysis. Journal of Comparative Economics, 43(1), 19-32. https://doi.org/10.1016/j.jce.2014.11.007

Majlesi, K., \& Narcico, G. (2018). International Import Competition and The Decision to Migrate: Evidence from Mexico. Journal of Development Economics, 132, 75-87. https://doi.org/10.1016/j.jdeveco.2017.12.002.

Makoto, R., \& Ngendakumana, L. (2018). Chinese Imports, Industrial Production, and Inflation in Zimbabwe. Journal of Chinese Economic and Foreign Trade Studies, 11(1), 2-14. https://doi.org/10.1108/JCEFTS-05-2017-0011.

Malgouyres, C. (2017). the Impact of Chinese Import Competition on the Local Structure of Employment and Wages: Evidence From France. Journal of Regional Science, 57(3), 411-441. https://doi.org/10.1111/jors. 12303

Mendez, O. (2015). The Effect of Chinese Import Competition on Mexican Local Labor Markets. The North American Journal of Economics and Finance, 34, 364-380. https:// doi.org/10.1016/j.najef.2015.09.009

Mion, G., \& Zhu, L. (2013). Import Competition From and Offshoring to China: A Curse or Blessing for Firms? Journal of International Economics, 89(1), 202-215. https://doi. org/10.1016/j.jinteco.2012.06.004

Nguyen, T. L., Van, H. V., Nguyen, L. D., \& Tran, T. Q. (2017). Does Rising Import Competition Harm Vietnam's Local Firm Employment of the 2000s? Economic Research, 30(1), 1882-1895. https://doi.org/10.1080/1331677X.2017.1392883.

Roodman, D. (2009). How to Do Xtabond2: An Introduction to Difference and System 
GMM in Stata. The Stata Journal, 9(1), st0159. Stata Journal, (1), 86-136. Retrieved from http://www.stata-journal.com/article.html?article=st0159

Taniguchi, M. (2019). The Effect of an Increase in Imports from China on Local Labor Markets in Japan. Journal of the Japanese and International Economies, 51, 1-18. https:// doi.org/10.1016/j.jjie.2018.09.001

Timmer, M. P., Erumban, A. A., Los, B., Stehrer, R., \& de Vries, G. J. (2014). Slicing Up Global Value Chains. Journal of Economic Perspectives, 28(2), 99-118.

Timmer, M. P., Dietzenbacher, E., Los, B., Stehrer, R., \& de Vries, G. J. (2015). An Illustrated User Guide to the World Input-Output Database: The Case of Global Automotive Production. Review of International Economics, 23, 575-605.

Vashisht, P. (2016). Creating Manufacturing Jobs in India: Has Openness to Trade Really Helped? Journal of Asian Economics, 42, 53-64. https://doi.org/10.1016/ j.asieco.2016.01.002

Wood, A., \& Mayer, J. (2011). Has China De-industrialised Other Developing Countries? Review of World Economics, 147(2), 325-350. 